Available online at:

https://ejournal.staindirundeng.ac.id/index.php/bashair/article/view/843

BASHA'IR

Jurnal Studi Alquran dan Tafsir

Published Desember 2021, 1(2): 95-104

P-ISSN: 2708-1018 | E-ISSN: 2708-100X

\title{
MENGENAL KETOKOHAN QURAISH SHIHAB SEBAGAI PAKAR TAFSIR INDONESIA
}

\author{
Reni Kumalasari \\ STAIN Teungku Dirundeng Meulaboh \\ reni.sekedang@gmail.com
}

\begin{abstract}
Abstrak
Quraish Shihab bukanlah satu-satunya pakar tafsir al-Qur'an di Indonesia, tetapi kemampuannya menerjemahkan dan menyampaikan pesan-pesan al-Qur'an dalam konteks kekinian dan masa modern membuatnya lebih unggul dari pada pakar al-Qur'an lainnya. Karya-karyanya tentang Al-Qur'an dapat dengan mudah diterima bukan hanya dari kalangan akademisi, tetapi masyarakat umum di nusantara. Penelitian ini bertujuan untuk mengakaji pemikiran Quraish Shihab dalam bidang Tafsir secara umum dengan menggunakan pendekatan literature review. Hasil penelitian menunjukkan bahwa Quraish Shihab adalah seorang ulama tafsir yang kompeten di nusantara. Ia berusaha menyentuhkan Al-Qur'an dengan realitas kehidupan manusia modern saat ini yang dibahasakan dengan istilah membumikan Al-Qur'an. Dalam hal metode, ia cenderung menggunakan tafsir tematik karena lebih tepat mengungkapkan kandungan Al-Qur'an mengenai berbagai persoalan umat Islam.
\end{abstract}

\begin{abstract}
Quraish Shihab is not the only expert on the interpretation of the Qur'an in Indonesia, but his ability to translate and convey the messages of the Qur'an in the present and modern context makes him superior to other Qur'anic experts. His works on the Qur'an can easily be accepted not only academics, but the general public. This study aims to examine the thoughts of Quraish Shihab in the field of tafsir in general by using a literature review approach. The results showed that Quraish Shihab was a competent commentator in the archipelago. He tries to touch the Qur'an with the reality of modern human life today which is called with the term grounding the Qur'an. In terms of method, he tends to use thematic interpretation because it is more appropriate to reveal the content of the Qur'an on various problems of Muslims today.
\end{abstract}

Keywords: Quraish Shihab, interpreter, interpretation, Al-Qur'an 


\section{Reni Kumalasari}

\section{A. PENDAHULUAN}

Tafsir adalah suatu usaha dalam menyingkap dan menangkap makna dibalik ungkapanungkap bahasa Al-Qur'an dengan maksud mentransfer paham dibalik lafazd yang tersurat. Baik dipandang dari sisi sebab-sebab turunnya al-Qur'an dan lokasi diturunkannya Al-Qur'an, termasuk juga hokum yang terkandung didalamnya.

Pada awalnya mufassir berasal dari golongan sahabat, tabiin dan tabi' tabiin (pengkut tabiin), dan penafsirannya ditulis dalam bahasa Arab, karena mereka hidup dikalangan orang-orang yang berbahasa Arab. Seiiring dengan berkembangnya zaman, maka muncul ulama-ulama nusantara yang menulis kitab tafsir dalam bahasa Indonesia, bahasa daerah dan bahasa Melayu yang sudah dimulai pada abad ke 17 M. Pada masa itu, Syeikh Abdur Rauf Singkili seorang ulama asal Aceh menyusun sebuah kitab tafsir pertama berbahasa Melayu yang diberi judul Turjuman al-Mustafid. Selanjutnya pada abad $19 \mathrm{M}$ hingga memasuki abad ke $20 \mathrm{M}$ ada beberapa mufassir Indonesia yang terkenal di nusantara, sebut saja Muhammad Yunus dengan Tafsir Al-Qur'an al-Karim dan Terjemahan Maknanya, kemudian Hasbi as-Shidieqy dengan Tafsir an-Nur, atau Hamka dengan Tafsir al-Azhar, dan Mufassir Indonesia saat ini yang masih bisa dijumpai sosoknya ialah Prof. Dr. M. Quraish Shihab.

M. Quraish Shihab bukanlah sosok yang asing di kalangan umat Islam nusantara. Ia dikenal sebagai ulama yang sering memberikan ceramah di sejumlah stasiun televisi atau media elektronik, khususnya selama bulan Ramadhan. Di kalangan akademisi ia adalah seorang mufassir terkemuka Indonesia dan guru besar dalam ilmu-ilmu Al-Qur'an.

Dalam tulisan ini akan dibahas lebih lanjut mengenai pemikiran Quraish Shihab khususnya dalam bidang tafsir Al-Qur'an, mengingat begitu besar pengaruhnya terhadap diskursus tafsir di nusantara. Hal ini dapat dilihat melalui banyaknya karyanya yang sering masuk dalam kategori best seller. Seperti kitab Tafsir al-Misbah, Membumikan Al-Qur'an, Wawasan Al-Qur'an dan lainnya.

\section{B. METODOLOGI PENELITIAN}

Penelitian ini merupakan penelitian kualitatif dengan menggunakan kajian kepustakaan (library reaserch), yaitu mengumpulkan data dari berbagai literatur yang ada hubungannya dengan penelitian ini. Sumber data dalam penelitian ini adalah data-data yang tersedia di pustaka terkait dengan ketokohan Quraish Shihab, di sini penulis mengambil pemikirannya yang tertuang dalam berbagai karyanya yang fenomenal seperti Membumikan Al-Qur'an, Wawasan Al-Qur'an, Tafsir AlMisbah, Jilbab dan karya-karya lainnya. Sementara data pendukung berupa sumber-sumber pustaka lainnya yang berkaitan dengan penelitian ini.

\section{HASIL DAN PEMBAHASAN}

\section{Biografi Quraish Shihab dan Karyanya Dalam Bidang Tafsir}

Prof. Dr. Muhammad Quraish Shihab lahir di Rappang, Sulawesi Selatan pada 16 Februari 1994. Pendidikan dasarnya diselesaikan di Ujung Pandang, kemudian melanjutkan pendidikan 
menengahnya di Pondok Pesantren Darul Hadis al-Fiqihiyyah Malang. Keluarganya merupakan keturunan Arab yang terpelajar. Ayahnya bernama Prof. Abdurrahman Shihab merupakan seorang ulama dan guru besar dalam bidang tafsir yang pernah menjabat sebagai Rektor IAIN Alauddin dan tercatat sebagai salah satu pendiri Universitas Muslim Indonesia (UMI) Ujung Pandang. Selain sebagai seorang ulama, ayahnya juga dipandang sebagai seorang pengusaha dan politikus yang memiliki reputasi baik di kalangan Sulawesi Selatan. Sejak kecil kecintaan terhadap ilmu Al-Qur'an sudah ada pada diri Quraish Shihab. Pada umur 6-7 tahun ia telah mengikuti pengajian Al-Qur'an yang diadakan ayahnya (Shihab, Membumikan Al-Qur'an: Fungsi dan Peran Wahyu dalam Kehidupan Masyarakat, 1999) .

Pada tahun 1958 Quraish Shihab beserta adiknya (Alwi Shihab) berangkat ke Kairo ,Mesir. Saat itu usia Quraish Shihab baru 14 tahun dan diterima di kelas dua I'dadiyah al-Azhar (setingkat SMP/Tsanawiyah di Indonesia). Sembilan tahun kemudian, tepatnya pada tahun 1967, ia meraih gelar Lc (S1) pada Fakultas Ushuluddin Jurusan Tafsir Hadis Universitas al-Azhar. Kemudian ia melanjutkan pendidikannya di fakultas yang sama. Pada tahun 1969 ia meraih gelar MA untuk spesialisasi bidang Tafsir Al-Qur'an dengan Tesis berjudul “al-l'jaz al-Tasyri' Al-Qur'an al-Adzim (Kemukjizatan Al-Qur'an al-Karim dari segi hukum)” (Shihab, Membumikan Al-Qur'an: Fungsi dan Peran Wahyu dalam Kehidupan Masyarakat, 1999).

Sepulang dari Mesir, M. Quraish Shihab dipercaya untuk menjabat wakil rektor bidang akademik dan kemahasiswaan pada IAIN Alauddin Ujung Pandang. Selain itu, ia juga diserahi jabatan-jabatan lain baik dalam maupun luar kampus. Pada tahun 1980, ia kembali lagi ke Kairo untuk melanjutkan pendidikannya di al-Azhar. Tahun 1982, ia berhasil meraih gelar doktor dalam ilmu-ilmu Al-Qur'an dengan yudisium summa cumlaude. Ia menulis disertasi yang berjudul "Nizam al-Durar li al-Biqa'iy Tahqiq wa Dirasah. Ia menjadi orang Asia Tenggara pertama yang meraih gelar Doktor dalam ilmu-ilmu Al-Qur'an di Universitas al-Azhar Mesir.

Tahun 1984 merupakan babak baru karir Quraish Shihab dimulai, yaitu saat ia pindah tugas dari Ujung Pandang ke IAIN Jakarta. Di sini ia aktif mengajar bidang tafsir dan Ilmu-ilmu Al-Qur'an di program S1, S2 dan S3 sampai pada tahun 1998. Selain menjadi rektor IAIN Jakarta selama dua periode (1992-1996 dan 1997-1998), ia juga dipercaya menjadi menteri agama kurang lebih dua bulan di awal tahun 1998 pada kabinet terakhir pemerintah Soeharto. Tahun 1999 sampai tahun 2002 ia dipilih menjadi duta besar luar biasa Republik Indonesia dan berkuasa penuh untuk Negara Republik Arab Mesir yang berkedudukan di Kairo.

Di sela-sela kesibukannya, Quraish Shihab masih sempat terlibat berbagai kegiatan ilmiah di dalam maupun luar negeri dan aktif melahirkan karya ilmiah yang fenomenal dalam bidang tafsir nusantara. Beberapa buku yang telah dihasilkannya ialah: Tafsir al-Manar: Keistimewaan dan Kelemahannya (Ujungpandang: IAIN Alauddin, 1984), Filsafat Hukum Islam (Jakarta: Departemen Agama, 1988), Membumikan Al-Qur'an: Fungsi dan Peran Wahyu dalam Kehidupan Masyarakat (Bandung: Mizan, 1996), Hidangan Ilahi Ayat-ayat Tahlil (Jakarta: Lentera Hati, 1997), Yang Tersembunyi (Jakarta: Lentera Hati, 1999), Tafsir al-Misbah: Pesan, Kesan dan Keserasian al-Qur'an 


\section{Reni Kumalasari}

(Jakarta: Lentera Hati), Logika Agama: Kedudukan Wahyu dan Batas-batas Akal dalam Islam (Jakarta: Lentera Hati, 2005), Jilbab (Jakarta: Lentera Hati, 2005) dan lainnya.

\section{Pemikiran Quraish Shihab di Bidang Tafsir}

Tafsir menurut Quraish Shihab adalah upaya memahami maksud firman-firman Allah sesuai dengan kemampuan manusia. Manusia yang ingin menyesuaikan sikap dan tindakannya dengan apa yang dikehendaki oleh Allah, maka ia harus dapat memahami pesan-pesan Al-Qur'an melalui tafsir. (Shihab, Membumikan Al-Qur'an: Fungsi dan Peran Wahyu dalam Kehidupan Masyarakat, 1999). Dengan demikian menurut Quraish Shihab tafsir memiliki urgensi yang sangat penting, ia berfungsi sebagai anak kunci untuk membuka khazanah Al-Qur'an, yang berarti sebagai pembuka pintu yang tertutup.

Setidaknya ada tiga alasan yang dikemukakan Quraish Shihab yang membuat dan menetukan tingginya signifikasi tafsir. (Shihab, Membumikan Al-Qur'an: Fungsi dan Peran Wahyu dalam Kehidupan Masyarakat, 1999)

1. Bidang yang menjadi kajian tafsir adalah kalam Ilahi yang merupakan sumber keagamaan dan segala ilmu pengetahuan.

2. Tujuan tafsir adalah untuk mendorong manusia berpegang teguh dan mengamalkan AlQur'an, demi tercapainya kebahagian dunia dan akhirat.

3. Beragamnya redaksi ayat Al-Qur'an, yakni ada yang jelas dan rinci, namun ada juga yang samar dan global, sehingga penafsiran terhadap ayat-ayat Al-Qur'an terasa sangat dibutuhkan.

Quraish Shihab banyak menekankan perlunya memahami wahyu Ilahi secara kontekstual dan tidak semata-mata berpaku pada makna tekstual, hal ini dilakukan agar pesan-pesan yang terkandung di dalamnya dapat difungsikan dalam kehidupan nyata. Ia menjelaskan bahwa setiap muslim wajib mempelajari dan memahami Al-Qur'an. Tetapi ini bukan berarti ia harus memahaminya sesuai dengan pemahaman orang terdahulu. Karena orang mukmin diperintahkan oleh Al-Qur'an untuk mempergunakan akalnya. Oleh karena itu menurutnya penafsiran terhadap Al-Qur'an tidak akan pernah berakhir. Dari masa ke masa selalu saja muncul penafsiran terbaru sejalan dengan perkembangan ilmu dan tututan kemajuan.

Sebagai contohnya, dahulu bahkan kini ulama-ulama menafsirkan kata al-alaq dalam ayatayat yang menjelaskan tentang proses janin dengan segumpal darah yang beku. Penafsiran ini ditemukan dalam kitab-kitab tafsr terdahulu dalam menafsirkan surah al-Mukmin ayat 14

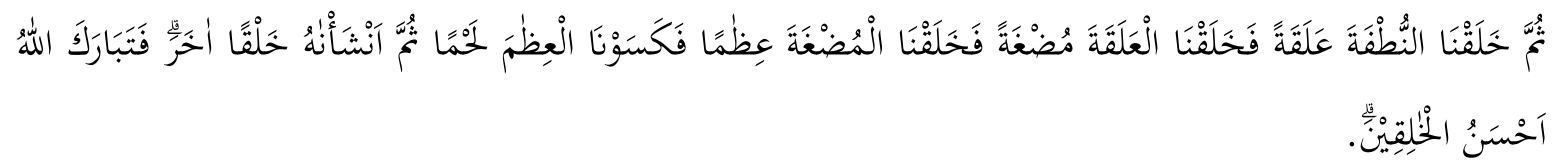

"Kemudian air mani itu kami jadikan segumpal darah, lalu segumpal darah itu kami jadikan segumpal daging, dan segumpal daging itu kami jadikan tulang belulang, lalu tulang belulang itu kami bungkus dengan daging. Kemudian kami jadikan dia makhluk yang (berbentuk) lain. Maka Maha sucilah Allah, Pencipta yang paling baik.” 
Berdasarkan ayat tersebut bahwa periode penciptaan manusia terdiri atas lima periode: alnutfah, al-Alaq, al-Mudghah, al'-idzam dan al-Lahm. Jelas bahwa al-alaq adalah periode kedua dari proses kejadian manusia.

Menurut embriologi dalam ilmu kedokteran proses kejadian manusia terbagi dalam tiga periode: Pertama, periode ovum. Periode ini dimulai dengan fertilasi (pembuahan) karena adanya pertemuan antara sperma dan ovum, yang selanjutnya kedua intinya bersatu dan membentuk struktur atau zat yang disebut zygote. Setelah fertilisasi berlansung, zygote membelah menjadi dua, empat, delapan dan seterusnya. Selama pembelahan ini, zygote menuju ke kantong kehamilan dan pada akhirnya melekat dan menggantung di dinding rahim (Shihab, Membumikan Al-Qur'an: Fungsi dan Peran Wahyu dalam Kehidupan Masyarakat, 1999)

Kedua, periode embrio. Yaitu periode pembentukan organ-organ. Terkadang organ tidak terbentuk dengan sempurna atau sama sekali tidak terbentuk, misalnya jika hasil pembelahan zygote tidak bergantung pada dinding rahim. Ini dapat mengakibatkan keguguran dan cacat bawaan. Ketiga, periode foetus. periode perkembangan dan penyempurnaan organ-organ, dengan perkembangan yang sangat cepat dan berakhir pada waktu kelahiran.

Dari sinilah terjadi penyesuaian antara embriologi dengan ilmu Al-Qur'an, periode ketiga disebut Al-Qur'an dengan al-mudghah merupakan periode kedua menurut embriologi, dimana dalam periode ini terbentuk organ-organ penting. Sedangkan periode keempat dan kelima menurut AlQur'an sama dengan periode ketiga yaitu foetus, penyempurnaan organ.

Al-Alaq yang oleh mufassirin diartikan dengan segumpal darah didapati bertentangan dengan hasil penyelidikan ilmiah. Karena ovum terdiri dari ektordem, endoderm dan rongga amnion. Unsurunsur ini tidak mengandung darah. Oleh karena itu penafsiran al-alaq yang tepat ialah diartikan sebagai sesuatu yang bergantung atau berdempet. Penafiran ini sejalan dengan embriologi yang dinamai implantasi dan sesuai dengan pengertian bahasa Arab. Al-Alaq dalam bahasa Arab berarti bergantungan atau berdempetan.

Maka menurut Shihab penafsiran terhadap Al-Qur'an belum berakhir, meskipun demikian ia tetap mengingatkan perlunya sikap teliti dan ekstra hati-hati dalam menafsirkan ayat Al-Qur'an, yaitu dengan tetap berpegang ketat pada kaidah-kaidah tafsir yang sudah dipandang baku. (alKhattan, 2009). Hal ini dimaksudkan agar seseorang tidak mudah mengklaim suatu pendapat sebagai pendapat Al-Qur'an.

Disamping itu, ia juga mengemukakan empat aspek yang hendaknya juga menjadi perhatian ulama-ulama atau mufassir ketika berhadapan dengan ayat-ayat Al-Qur'an:

1. Perubahan sosial

Al-Qur'an baik secara implisit maupun eksplisi mengakui tentang kenyataan perubahan sosial, perubahan yang mutlak harus terjadi, cepat atau lambat, disadari atau tidak. Ditemukan banyak ayat Al-Qur'an yang berbicara tentang ini, antara masyarakat ideal yang sifatnya adalah masyarakat yang terus berkembang kea rah positif (QS 48: 29) dan setiap masyarakat mempunyai batas usia (QS 10:49, 15:5) dan lain-lain. 


\section{Reni Kumalasari}

Seorang dalam menafsirkan ayat-ayat Al-Qur'an hendaknya memahami lingkungan budaya dimana ia berada. Memperhatikan kemampuan, tingkat, kecenderungan dan kondisi yang berbedabeda. Seorang mufassir dituntut untuk menjelaskan nilai-nilai itu sejalan dengan perkembangan masyarakatnya. Sehingga Al-Qur'an dapat benar-benar berfungsi sebagai petunjuk, pemisah antara yang haq dan bathil serta pemberi solusi bagi setiap problem kehidupan yang dihadapi.

2. Perkembangan Ilmu Pengetahuan

Sebagian ulama berpendapat bahwa Al-Qur'an dan hadis harus difahami berdasarkan masa turunnya. Menurut Quraish Shihab ini mengakibatkan pembatasan dalam memahami teks-teks AlQur'an. Pemahaman disiplin ilmu dan pengetahuan pada masa turunnya Al-Qur'an sangat jauh terbelakang dengan dengan perkembangan ilmu saat ini. Al-Qur'an menurutnya diturunkan untuk semua manusia di setiap masa dan Al-Qur'an memerintahkan untuk setiap orang berfikir, maka tentunya setiap orang berfikir antara lain berdasarkan perkembangan ilmu pengetahuan itu sendiri. (al-Khattan, 2009).

Sebagai contoh ketika ilmu pengetahuan membuktikan secara pasti bahwa bumi ini bulat, maka mufassir masa kini akan memahami dan menafsirkan firman Allah "dan Allah jadikan untuk kamu bumi ini terhampar" (QS. 71:19), bahwa kehamparan yang dimaksud tidak bertentangan denga teori bentuk kebulatannya, karena ketehamparan ini terlihat oleh pandangan mata dan disaksikan oleh siapapun dan kemanapun seseorang melangkahkan kakinya.

Demikian pula ketika eksperimen membuktikan bahwa para ahli medis telah dapat menditeksi jenis janin bayi dalam kandungan, maka pemahaman terhadap ayat "Allah mengetahui apa yang dikandung oleh setiap perempuan" (QS. 13:8). Pemahaman kata "apa" beralih dari yang tadinya dipahami oleh mufassir terdahulu sebagai jenis kelamin bayi menjadi lebih umum dari sekedar jenisnya, sehingga mencakup masa depan, bakat, jiwa, dan segala perinciannya.

3. Bahasa

Sudah menjadi kesepakan baku di kalangan mufassir bahwa bahasa Arab merupakan faktor penting untuk bisa memahami kandungan Al-Qur'an, namun penting juga memperhatikan perkembangan bahasa itu sendiri. Bila mendengar suatu kata yang tergambar dalam benak kita adalah gambaran materil yang menyangkut kata tersebut, namun di lain sisi bentuk materil tersebut dapat mengalami perkembangan sesuai dengan perubahan masyarakt. Misalnya kata dzarrah pada masa turunnya Al-Qur'an maknanya berkisar pada kepala semut, debu-debu yang berterbangan dan lain-lain, sedangkan kini ia memiliki tambahan arti yang tadinya belum dikenal, yaitu atom.

Quraish Shihab menyakini Al-Qur'an mampu berdialog dengan seluruh umat manusia sepanjang masa, namun demikian ia menegaskan tidak wajar untuk menonjolkan segi-segi perbedaan tersebut. Karena pada akhirnya akan melahirkan tafsir Al-Qur'an ala Indonesia, Malaysia, Dubai atau negara Islam lainnya. Namun yang terpenting dan menjadikan kewajiban bagi umat Islam seluruhnya ialah menjadikan ajara Al-Qur'an menyentuh realitas kehidupan umat manusia. Shihab menulis:

"Menjadi kewajiban umat Islam untuk membuikan Al-Qur'an, menjadikannya menyentuh

realitas kehidupan. Semua manusia berkewajiban memilihara Al-Qur'an dan salah satu [100] Basha'ir: Jurnal Studi Alquran dan Tafsir 
bentuk pemeliharaannya adalah memfungsikannya dalam kehidupan kontemporer, yakni dengan memberinya intrepretasi yang sesuai tanpa mengorbankan teks sekaligus tanpa mengorbankan kepribadian, budaya bangsa, dan perkembangan politik masyarakat."

\section{Metode Penafsiran Quraish Shihab}

Setiap mufassir memiliki metode masing-masing dalam menafsirkan ayat Al-Qur'an yang berbeda dengan mufassir lainnya. Selama ini metode tafsir yang berkembang ada empat macam: tahlili, ijmali, muqarran dan maudhu'i. (Al-Farmawi, 1994)

Adapun metode yang cenderung digunakan oleh Quraish Shihab dalam menafsirkan AlQur'an ialah metode maudhui dan metode tahlili.

1. Metode maudhu'i

Quraish Shihab sering menekankan pentingnya penggunaan metode tafsir maudhui (tematik), ini terlihat dari banyaknya jumlah kitab tafsirnya yang menggunakan metode ini. Metode maudhu'i ialah penafsiran dengan cara menghimpun sejumlah ayat Al-Qur'an yang tersebar dalam berbagai surah yang membahas masalah yang sama, kemudian menjelaskan pengertian menyeluruh dari ayat-ayat tersebut dan selanjutnya menarik kesimpulan sebagai jawaban terhadap masalah yang menjadi pokok bahasan. Menurutnya, dengan metode ini dapat diungkap berbagai pendapat Al-

Qur'an tentang berbagai masalh kehidupan, sekaligus dapat dijadikan bukti bahwa ayat Al-Qur'an sejalan dengan perkembangan iptek dan kemajuan peradaban masyarakat.

Sebagai contoh, Shihab menjelaskan tentang jihad sebagai salah satu persoalan penting yang hidapi umat Islam saat ini. Ia menghimpun berbagai ayat Al-Qur'an yang berbicara mengebai jihad, diantaranya ialah surah al-Baqarah: 73, al-Tahrim: 9, Yusuf: 53. dari berbagai ayat di atas Shihab berkesimpulan bahwa jihad tidak hanya dalam bentuk melawan orang kafir secara fisik, tetapi lebih luas dari itu. Menurutnya jihad memberantas kebodohan, kemiskinan, dan penyakit adalah jihad yang tak kalah pentingnya dari sekedar mengangkat senjata. (Shihab, Wawasan Al-Qur'an, 1998) Dengan demikian terlihat bahwa Quraish Shihab berusaha menahami kembali makna jihad yang sebenarnya dalam konteks kekinian sesuai dengan ruh Al-Qur'an.

\section{Metode Tahlili}

Metode tahlili (analitik) adalah sebuah bentuk karya tafsir yang berusaha untuk mengungkapkan kandungan Al-Qur'an dari berbagai aspeknya. Bentuk ini disusun berdasarkan urutan ayat di dalam Al-Qur'an, selanjutnya memberikan penjelasan tentang kosa kata, makna global ayat, kolerasi, asbabun nuzul dan hal-hal lain yang dianggap bisa membantu dalam memahami ayat Al-Qur'an. (al-Farmawi, 1980)

Quraish Shihab menggunakan metode tahlili dalam Tafsir al-Misbah, sebuah karya monumentalnya yang sangat terkenal yang diterbitkan oleh lentera hati. Tafsir al-Misbah adalah sebuah tafsir Al-Qur'an lengkap 30 juz pertama dalam kurun waktu 30 tahun terakhir. Warna keindonesian penulis memberi warna yang menarik dan khas serta relavan dalam memperkaya khazanah pemahaman dan penghayatan umat Islam terhadap rahasia makna ayat Allah swt. 


\section{Reni Kumalasari}

Kelebihan dari tafsir al-Misbah ialah: pertama, menjelaskan petunjuka ayat Al-Qur'an yang berkaitan langsung dengan kehidupan masyarakat dan menjelaskan bahwa Al-Qur'an itu kitab suci yang kekal sepanjang zaman. Kedua, penjelasan-penjelasan lebih tertuju pada penanggulangan penyakit dan masalah-masalah yang sedang mengemuka dalam masyarakat. Ketiga, disajikan dengan bahasa yang mudah dipahami dan didengar. Salah satunya penafsirannya pada surat al-Mu'minun tentang pembebasan perbudakan yang dikaitkan dengan persoalan PHK (pemutusan hubungan kerja) (Shihab, Tafisr al-Misbah: Pesan, Kesan dan Keserasian Al-Qur'an, 2006).

\section{Kritikan Terhadap Quraish Shihab}

Dengan ketokohan serta ilmu yang dimiliki, tak membuat Quraish Shihab menjadi sosok yang terlepas dari kritikan. Salah satunya ialah ia dianggap memiliki pemikiran sebagai bentuk dukungan terhadap pemahaman Syiah, bahkan oleh sebagian orang ia dianggap sebagai agen syiah. Berikut beberapa tulisan Quraish Shhab yang tersebar di berbagai bukunya yang menurut sebagian orang merupakan bentuk dukungan terhadap Syiah:

"Ada juga pengelompokan-pengelompokan seperti Ahl Sunnah wa al-Jamaah, Syiah dan sebagainya. Semua mengaku Ahl Sunnah wa Jamaah, apalagi kita di Idonesia, lebih sempit lagi NU menganggap hanya kelompoknya yang ahl sunnah wa jamaah. Ya akhi, kita semua ahl sunnah wa jamaah. Semua kita, baik Muhammadiyah, NU, maupun Syiah.” (Shihab, Satu Islam Sebuah Dilema, 1994)

Di dalam tulis lain Shihab menjelaskan: "Tauhid pada prinsipnya adalah kekuasan Tuhan dalam sifat, perbuatan, dan DzatNya, serta kewajiban mengesakan dalam beribadah kepadaNya. Dalam butir-butir makna tauhid di atas, tidak dijumpai perbedaan prinsipil antara ahl sunnah dan syiah.” (Shihab, Sunnah-Syiah Bergandengan Tangan! Mungkinkah?. Kajian Atas Konsep Ajaran dan Pemikiran,, 1997)

Tulisan ini dibantah oleh para pengajar dari Pondok Pesantren Sidogiri dengan buku yang berjudul, "Mungkinkah Sunnah-Syiah dalam Ukhuwah: Jawaban Atas Buku Dr. Quraish Shihab". Buku ini memuat bantahan terhadap ungkap Quraish Shihab bahwa tidak dijumpai perbedaan prinsipil antara ahl Sunnah dan Syiah.

Selain kritikan di atas, ia juga dikritik atas pendapatnya yang menempatkan jilbab (penutup aurat) pada posisi khilafiah. Menurutnya, ayat-ayat Al-Qur'an yang berbicara tentang pakaian wanita mengandung aneka interpretasi. Hadis yang merupakan rujukan utama dinilai tidak menyakinkan pihak lain, baik dinilai lemah oleh pihak yang menolaknya atau diberi intrepretasi yang berbeda. Selain itu, ketetapan hukum batas yang ditolerir dari aurat atau badan wanita bersifat zhanny yakni dugaan semata.Quraish juga bersikap, bahwa adanya berpedaan pendapat para pakar hukum tentang batasan aurat adalah perbedaan pendapat manusia yang mereka kemukan dalam kontes situasi zaman serta kondisi masa dan maasyarakat mereka, serta pertimbangan nalar mereka, dan bukannya hukum Allah yang jelas dan tegas. Ia menulis:

"Wanita yang menutup seluruh badannya atau kecuali wajah dan telapak tangannya telah menjalankan bunyi teks-teks ayat atau mungkin lebih. Dalam saat yang sama kita tidak wajar menyatakan terhadap mereka yang tidak memakai kerudung atau yang menampakkan 
setengah badannya, bahwa mereka secara pasti telah melanggar petunjuk agama. Bukankah Al-Qur'an tidak menunjukkan batas aurat?, para ulama pun ketika membahasnya berbeda pendapat. Namun kehati-hatian sangat dibutuhkan. Demikian juga pakaian bathin, apabila tidak sesuai dengan jati diri manusia sebagai hamba Allah, yang paling mengetahui patron dan ukuran yang terbaik bagi manusia."

Pandangan Quraish Shihab diatas yang menganggap permasalahan jilbab sebagai masalah khilafiyah yang tidak memiliki dalil pasti akan keharusan memakainya, sering dikaitakan oleh masyarakat muslim Indonesia dengan salah satu anaknya yang berprofesi sebagai public figure yaitua Najwa Shihab, yang tidak mengenakan jilbab saat menjadi pembawa acara televisi swasta di Indonesia.

\section{KESIMPULAN}

Quraish Shihab adalah seorang ulama tafsir yang kompoten. Kemampuannya menyampaikan ayat-ayat Al-Qur'an dalam konteks kekinian menawarkan udara baru dalam bidang tafsir khususnya di wilayah nusantara. Dalam hal metode penafsiran ia cenderung menggunakan tafsir tematik karena lebih tepat mengungkapkan pesan-pesan Al-Qur'an mengenai berbagai persoalan umat Islam. Melalui tafsirnya ia berusaha untuk menjadikan Al-Qur'an dapat menyentuh realitas kehidupan manusia kontemporer saat ini, ia membahasakannya dengan istilah membumikan Al-Qur'an. Oleh karena menurutnya penafsiran terhadap Al-Qur'an tidak akan pernah berakhir, selalu akan muncul penafsiran sejalan dengan perkembangan iptek dan kemajuan peradaban manusia.

Kelebihan-kelebihan tersebut dan keluasan ilmunya di bidang ilmu Al-Qur'an membuatnya lebih unggul dari para mufassir nusantara lainnya. Meskipun demikian, tidak ada manusia yang sempurna, tidak ada gading yang tak retak, dan tidak ada pemikiran yang tak dicela. Pemahamannya tentag perbedaan kelompok dalam Islam serta penafsirannya tentang jilbab sebagai pakaian wanita Islam sering mendapatkan kritikan.

\section{DAFTAR PUSTAKA}

Al-Farmawi, A. A.-H. (1994). Metode Tafsir Maudhu'I . Jakarta: Grafindo.

Al-Farmawi, M. I. (1980). Dirasah fi Tafsir al-Maudhu'I . Kairo: Dar al-Taufiqiyah.

Al-Khattan, M. (2009). Pengantar Studi Ilmu Al-Qur'an,. (A. Rafiq, Trans.) Jakarta: Pustaka al-Kautsar. 


\section{Reni Kumalasari}

Shihab, M. Q. (1994). Satu Islam Sebuah Dilema. Bandung: Mizan.

Shihab, M. Q. (1997). Sunnah-Syiah Bergandengan Tangan! Mungkinkah?. Kajian Atas Konsep Ajaran dan Pemikiran,. Jakarta: Lentera Hati.

Shihab, M. Q. (1998). Wawasan Al-Qur'an. Bandung: Mizan.

Shihab, M. Q. (1999). Membumikan Al-Qur'an: Fungsi dan Peran Wahyu dalam Kehidupan Masyarakat. Bandung: Mizan.

Shihab, M. Q. (2005). Jilbab: Pakaian Wanita Muslimah. Jakarta: Lentera hati.

Shihab, M. Q. (2006). Tafisr al-Misbah: Pesan, Kesan dan Keserasian Al-Qur'an. Jakarta: Lentera Hati. 